\author{
Karolina Kinga FIGASZEWSKA \\ https://orcid.org/0000-0001-9177-4375 \\ Instytut Historii Nauki im. Ludwika i Aleksandra Birkenmajerów \\ Polskiej Akademii Nauk
}

\title{
Fragmenty rękopisów średniowiecznych - stan badań i perspektywy badawcze. Średniowieczne fragmenty zachowane w Archiwum Państwowym w Szczecinie*
}

Zarys treści: $\mathrm{W}$ ostatnich latach średniowieczna makulatura rękopiśmienna stała się obiektem intensywnych badań w różnych ośrodkach naukowych na całym świecie. Mimo ogromu włożonej pracy wciąż w wielu miejscach pozostaje jednak materiałem nieprzebadanym. W artykule zaprezentowano inicjatywy podejmowane $\mathrm{w}$ celu opracowania i zdigitalizowania rękopiśmiennej makulatury średniowiecznej. Tekst zawiera również wstępne ustalenia z kwerend przeprowadzonych w Archiwum Państwowym w Szczecinie, Bibliotece Narodowej oraz Archiwum PAN w Warszawie, w trakcie których udało się odkryć ponad tysiąc średniowiecznych fragmentów rękopiśmiennych wykorzystanych wtórnie jako oprawy jednostek archiwalnych. Zachowane fragmenty umożliwiają częściowe zrekonstruowanie całych kodeksów oraz rzucają nowe światło na niemal całkowicie nieznane średniowieczne księgozbiory instytucjonalne na Pomorzu Zachodnim.

\begin{abstract}
In recent years, medieval "wastepaper baskets" of manuscripts have become the subject of intense research in various scientific centres around the world. Despite the enormous work done by researchers, it still remains unexplored in many places. The article presents initiatives taken to work out and digitize medieval manuscript fragments. The text also contains preliminary establishments from queries carried out in the State Archives in Szczecin, the National Library and the Archives of the Polish Academy of Sciences in Warsaw, during which more than a thousand medieval manuscript fragments were found being reused as bindings of archival units. The preserved fragments make it possible to partially reconstruct entire codices and shed new light on the almost completely unknown medieval official book collections in Western Pomerania.
\end{abstract}

Słowa kluczowe: fragmentologia, Archiwum Państwowe w Szczecinie, oprawy, rękopisy, Pomorze Zachodnie

Keywords: fragmentology, State Archives in Szczecin, bindings, manuscripts, Western Pomerania

W zbiorach polskich stopniowo przybywa średniowiecznej makulatury, odnajdywanej w trakcie opracowywania zbiorów lub wyodrębnianej z rękopisów podczas konserwacji. Przeważnie obiekty te, po zaspokojeniu ciekawości badaczy, trafiają do teczek, pudeł lub szuflad, w najlepszym wypadku do okładek z niekwasowego papieru, gdzie zresztą zwykle ulegają zapomnieniu. W znakomitej większości

\footnotetext{
* Artykuł zawiera wstępne wnioski dotyczące średniowiecznych fragmentów rękopiśmiennych z Archiwum Państwowego w Szczecinie, powstał w ramach projektu badawczego „Inwentarz dziedzictwa narodowego w zakresie rękopisów średniowiecznych" finansowanego przez Ministerstwo Nauki i Szkolnictwa Wyższego na podstawie umowy nr 0084/NPRH5/ H11/84/2017 (Narodowy Program Rozwoju Humanistyki); zob. http://manuscripta.pl/.
} 
fragmenty te nie są szczegółowo opisywane, nie mają osobnej sygnatury, a same instytucje (i ich pracownicy) niekiedy nie mają nawet świadomości wielkości takiego zbioru. Okoliczności te uniemożliwiają w konsekwencji oszacowanie ostatecznej liczby fragmentów znajdujących się w bibliotekach i archiwach polskich.

Według hasła w Encyklopedii wiedzy o książce makulaturę stanowią papierowe lub pergaminowe karty z niepotrzebnych rękopisów, druków i próbnych odbitek, które wtórnie wykorzystywano w warsztatach introligatorskich do wykonania zszywek, wyklejek, kart ochronnych oraz kompaturek, czyli opraw powstałych na skutek połączenia ze sobą wielu arkuszy papieru lub ich fragmentów ${ }^{1}$. Definicja ta jest jednak bardzo ogólna i szeroka, makulaturą bowiem nie są tylko i wyłącznie elementy kodeksów, ale także inne obiekty papierowe lub pergaminowe (np. karty do gry²), nadające się do wykorzystania w procesie oprawiania książki. Chcąc doprecyzować ten termin, należy podzielić makulaturę na trzy grupy: 1) materiały rękopiśmienne lub drukowane niestanowiące pierwotnie części kodeksu, np. listy i dokumenty, 2) materiały rękopiśmienne lub drukowane będące pierwotnie częścią kodeksu lub docelowo mające stanowić część kodeksu, ale odrzucone, np. ze względu na błąd w druku, tj. fragmenty sensu stricto oraz 3 ) inne - pergaminowe lub papierowe - obiekty wykorzystane przez introligatora w procesie oprawiania książki. Idąc dalej, należy doprecyzować termin „fragment” w ścisłym tego słowa znaczeniu. Wyróżnić można dwa rodzaje fragmentów: luźne bądź stanowiące część zabytku, niekoniecznie książki. Za fragment luźny uznać należy celowo odłączony lub oderwany w skutek uszkodzenia lub innego niecelowego działania element rękopisu lub druku. W założeniu ten rodzaj fragmentu mógł nie być nawet połączony z blokiem książki, lecz funkcjonować osobno, np. w postaci średniowiecznej zakładki. Do tej grupy zaliczyć należy wszystko - od małego skrawka, przez fragment karty, całą kartę, fragment bifolium aż po całe bifolium.

Fragmenty stanowiące część zabytku to przeważnie karty z rękopisu, użyte wtórnie jako element konstrukcyjny, wzmacniający i/lub chroniący blok książki przed zniszczeniem, rzadziej pełniący funkcję estetyczną. Podkreślić należy, że fragment taki używany był przede wszystkim ze względu na materiał (zwłaszcza pergamin), treść zwykle nie odgrywała żadnej roli. Za makulaturę użytą ze względów estetycznych uznać można np. jednostronnie zapisany dokument, który został przyklejony do oprawy stroną zapisaną. Grupa ta, ze względu na specyfikę, jest obszerniejsza i bardziej złożona. Najczęściej makulatura tego rodzaju wykorzystywana była jako elementy przybyszowe, tj. wszystkie części dodawane przez introligatora $\mathrm{w}$ procesie oprawiania książki, których główną funkcją była ochrona bloku książki i/lub jego połączenie z oprawą oraz wzmocnienie połączenia bloku książki z okładką. Funkcje takie pełniły: wyklejka i półwyklejka, karta ochronna i cząstkowa karta ochronna, falc, scyzura, pseudoscyzura, zszywka i zszywka nieciągła oraz wyklejenie grzbietu ${ }^{3}$.

Kolejnym sposobem wykorzystywania takich fragmentów były oprawy, których wyróżnić można kilka rodzajów: kompaturki tworzone przez połączenie większej ilość kart i/lub bifoliów w taki sposób, aby tworzyły sztywną oprawę; obleczenie, tj. jako materiał oblekający grzbiet oraz okładziny wykonane $\mathrm{z}$ desek; oklejenie okładzin, tj. wyrównanie oprawy za pomocą kart przyklejonych do deski przed jej obleczeniem; oprawy miękkie wykonane z kart i/lub bifoliów (niekiedy pozszywanych) oraz obwoluty. Ostatnie dwa rodzaje opraw najczęściej spotkać można w archiwach. Do tej grupy należą także inne, nie zawsze dla nas jasne sposoby zastosowania omawianych fragmentów - tenacula, małe fragmenty wklejone gdzieś w środek kodeksu, sznurki wykonane z poskręcanych fragmentów kart pergaminowych, etc. Kreatywność introligatorów była pod tym względem ogromna. Do tej grupy zaliczam także przedmioty wykonane z papieru lub pergaminu, który nie pochodziły z rękopisów lub przedmioty wykonane

\footnotetext{
${ }^{1}$ Encyklopedia wiedzy o książce, red. A. Birkenmajer, Wrocław 1971, szp. 1451; A. Zawisza, Kompaturki - nowe podejście do problemu, „Notes Konserwatorski”, 15, 2012, s. 149.

${ }^{2}$ H. Rosenfeld, Kalender und andere Funde in Buch- und Archivalienbänden, „Mitteilungen für die Archivpflege in Bayern”, 8, 1962, s. 19 n.

3 Terminologia omówiona szczegółowo w: E. Chlebus, Elementy przybyszowe w oprawach późnogotyckich - formy, funkcje, terminologia, „Roczniki Biblioteczne”, 61, 2017, s. 70.
} 
częściowo lub w pełni z kart kodeksów rękopiśmiennych, głównie pergaminowych, jak np. ubrania ${ }^{4}$ czy mitra biskupia ${ }^{5}$. Stanowią one jednak odrębną problematykę.

W świetle przytoczonych wyżej definicji karty rękopiśmienne ułożone w składki i współoprawne $\mathrm{z}$ inkunabułami lub drukami nie są fragmentami, lecz adligatami. Za adligat uznać należy rękopiśmienną część klocka introligatorskiego, która stanowi integralną część kodeksu, zależną bądź niezależną od treści druku, ale współoprawną z drukiem.

Problemem pozostają fragmenty niezapisane lub uchodzące za niezapisane, np. ze względu na połączenie z kodeksem w sposób uniemożliwiający stwierdzenie, czy noszą one ślady pisma. Fragmentów tych nie bierze się pod uwagę w badaniach, lecz należy odnotować ich istnienie. Nierzadko bez demontażu grzbietu lub też dokładnej konserwacji nie da się określić, czy kodeks w ogóle zawiera makulaturę, gdyż w przypadku dobrze zachowanych opraw pozostaje ona niewidoczna. W wypadku kodeksów o złym stanie zachowania obecność makulatury można stwierdzić jedynie na podstawie odbitych śladów tekstu. W znakomitej większości przypadków nigdy nie dowiemy się, co się z nią stało. Problem makulatury wciąż pozostającej w kodeksach stanowi punkt zapalny w dyskusjach naukowców i konserwatorów. Podczas gdy jedni postulują całkowite rozłożenie obiektu na części i usunięcie fragmentów rękopiśmiennych, drudzy naciskają na ingerowanie w obiekt w jak najmniejszym stopniu i pozostawienie fragmentów jako integralnych części rękopisu lub starego druku.

Praktyka wykorzystywania szeroko pojętej makulatury przez introligatorów miała miejsce już w XIII i XIV w., ale na popularności zyskała dopiero pod koniec XV w., wraz z pojawieniem się książki drukowanej oraz w okresie reformacji, gdy likwidowano niektóre klasztory. Była ona stosowana nawet do XVII w., gdy zaprzestano produkcji rękopisów (zwłaszcza pergaminowych), introligatorzy nie dysponowali już zatem materiałem, który mogliby ponownie wykorzystać, a sama praktyka oprawiania książek ewoluowała na tyle, że zaprzestano wtórnego wykorzystywania rękopisów. Jednakże dzięki tym „niszczącym” działaniom introligatorów zachowały się liczne, nieraz bardzo cenne, niepowtarzalne zabytki rękopiśmienne, stanowiące dla nas źródło wiedzy, nie tylko na temat samych tekstów i praktyki czytelniczej, ale także proweniencji, księgozbiorów oraz samej produkcji książki średniowiecznej i wczesnonowożytnej.

Możemy jedynie przypuszczać, w jaki sposób makulatura trafiała do rąk introligatora. Ze względu na trwałość materiału najczęściej wykorzystywano rękopisy pergaminowe, rzadziej papierowe. Fragmenty mogły pochodzić z kodeksów „zużytych”, tzn. w znacznym stopniu zniszczonych i/lub zaczytanych. Mogły to być również rękopisy, które straciły na aktualności (np. niektóre księgi liturgiczne po soborze trydenckim), albo też zostały uznane za nieprzydatne, chociażby z racji nieczytelności pisma (np. rękopisy pisane minuskułą gotycką w okresie nowożytnym) lub zastąpienia potrzebnego tekstu przez inny egzemplarz (np. drukowany). $Z$ pewnością makulatura trafiała do introligatora także na fali reformacyjnej likwidacji kościołów i zborów lub modyfikacji ich przeznaczenia na skutek zmiany wyznania przez użytkujących te świątynie wiernych. Problem nie dotyczy zresztą wyłącznie rękopisów średniowiecznych. W chwili upowszechnienia druku makulaturę zaczęły stanowić także „odpady” z drukarń, czyli zbędne, wydrukowane $\mathrm{z}$ błędami lub uszkodzone w procesie drukowania karty.

Częściami oprawy, na których zazwyczaj starał się zaoszczędzić introligator, były elementy przybyszowe. Gdy pochodziły z jednego rękopisu i zostały wykorzystane w procesie oprawiania więcej niż jednej książki można czasami określić czas i miejsce powstania tych opraw, a w konsekwencji wnioskować na temat pochodzenia wykorzystanego na oprawę rękopisu. W wypadku kart przybyszowych oraz opraw wykorzystywane były całe karty i bifolia. W niektórych wypadkach umożliwia to zrekonstruowanie znacznej części pierwotnego kodeksu. Jest to jednak rzadko spotykana praktyka. Częściej liczba zachowanych fragmentów umożliwia jedynie zidentyfikowanie ich jako pochodzących z tego

\footnotetext{
${ }^{4}$ Zob. Ch. Klack-Eitzen, W. Haase, T. Weißgraf, Heilige Röcke. Kleider für Skulpturen in Kloster Wienhausen, Regensburg 2013; Fragment und Makulatur. Überlieferungsstörungen und Forschungsbedarf bei Kulturgut in Archiven und Bibliotheken, red. H.P. Neuheuser, W. Schmitz, Wiesbaden 2015.

${ }^{5}$ Handrit.is, Fragment AM 666 b 4to, <https://handrit.is/en/manuscript/view/en/AM04-0666-b> [dostęp: 11.02.2018].
} 
samego rękopisu, czasami z dokładnością do składki. Tylko w nielicznych wypadkach udaje się znaleźć na tyle dużo elementów, by móc następnie zrekonstruować znaczną część lub nawet całą składkę. Należy stwierdzić, że pełna rekonstrukcja książki, z której wykorzystano karty w roli makulatury, jest niemożliwa, chociażby dlatego, że jej elementy wykorzystywano nie tylko w celach introligatorskich, ale także w wielu przedmiotach codziennego użytku. Jednak nawet tak fragmentarycznie zachowana książka jest lepszym źródłem informacji niż pojedyncze, do niczego niepasujące elementy.

Niezależnie od reprezentatywności zbioru makulatury (fragmenty, karty czy bifolia) istotną trudność w składaniu fragmentów stanowi sama identyfikacja tekstów i ręki kopisty. Należy pamiętać, że kopista mógł przepisać więcej niż jeden tekst i to, co na pierwszy rzut oka może się wydawać jako pochodzące $\mathrm{z}$ jednego rękopisu w rzeczywistości może być osobnymi egzemplarzami powstałymi w tym samym warsztacie pisarskim (skryptorium).

Już od początku XIX w. makulatura oraz całe rękopisy stały się obiektem zainteresowania kolekcjonerów, którzy wyodrębniali poszczególne elementy (składki z tekstami, ale też pojedyncze karty) z kodeksów w celu powiększenia kolekcji prywatnej lub sprzedaży. W ten sposób zarówno utracono, ale też i pozyskano sporą ilość fragmentów. Do powstawania zbiorów makulatury w równym stopniu przyczyniała się także konserwacja zabytków oraz działalność bibliotekarzy, archiwistów i badaczy wielu dziedzin, wydobywających makulaturę z poszczególnych jednostek, a na ich uwagę z reguły zasługiwały jedynie ciekawe obiekty. Zwykle jednak nie opisywano makulatury, lecz tylko gromadzono w kategorii „materiałów luźnych” (w teczkach lub pudłach). Obecnie przy opisywaniu niektórych rękopisów średniowiecznych o pierwotnej obecności fragmentów świadczą jedynie ślady odbitego tekstu na oprawie, grzbiecie lub pierwszej karcie bloku.

Rękopiśmienna makulatura średniowieczna od niemal dwustu lat stanowi obiekt zainteresowania badaczy reprezentujących różne dyscypliny. Jej pierwszymi odkrywcami byli bibliotekarze i archiwiści, którzy podczas opracowywania zbiorów dokonywali przypadkowych odkryć i własnoręcznie odłączali makulaturę od obiektu ${ }^{6}$. $Z$ czasem zainteresowali się nią także filolodzy i historycy - w pierwszej kolejności poszukujący makulatury w językach rodzimych, a z czasem także muzykolodzy ${ }^{7}$. Wówczas najczęściej wydobywano makulaturę z zabytków, a w konsekwencji tych działań w wielu wypadkach bezpowrotnie utracono cenną wiedzę na temat budowy kodeksów, m.in. sposobu wykorzystania makulatury, a w nielicznych wypadkach także i proweniencji ${ }^{8}$. Przyniosło to także ogromną stratę dla samych badań nad fragmentami, wiele $\mathrm{z}$ wyodrębnionych $\mathrm{w}$ ten sposób części zostało bowiem bezpowrotnie utraconych w skutek kradzieży, zagubienia lub zniszczenia. Najczęściej jednak przyjmowano założenie, że fragmenty stanowią nieodłączny element kodeksu i pozostawiano je na miejscu, uważając, że kodeks, o ile to możliwe, powinien zostać zachowany w stanie, w którym przetrwał do naszych czasów, a więc z nienaruszoną strukturą wykorzystanych przez introligatora elementów.

Badania nad fragmentami rozwijały się niezależnie niemal we wszystkich krajach europejskich, w których zachowały się zbiory biblioteczne i archiwalne sięgające średniowiecza. Rozwój ten przebiegał w dość podobny sposób, można więc mówić o pewnych tendencjach. Pierwsze publikacje zawierające informacje o rękopiśmiennej makulaturze średniowiecznej zaczęły się pojawiać w XVIII w., a ich początki związane są głównie z działalnością bibliotekarzy i archiwistów, którzy w codziennej pracy dokonywali ciekawych, aczkolwiek przypadkowych znalezisk ${ }^{9}$. Upubliczniali oni najczęściej ogólne

\footnotetext{
${ }^{6}$ Przykładowo zob. K.A. Barack, Die Handschriften Fürstlich-Fürstenbergischen Hofbibliothek zu Donaueschingen, t. 1-2, Tübingen 1865; P.A. Munch, Levninger af norsk Oldlitteratur, nylig opdagede i det norske Rigsarkiv, „Norsk Tidsskrift for Vindenskab og Litteratur", 1, 1847, s. 25-52.

7 Przykładowo zob. O. Fleischer, Die germanischen Neumen als Schlüssel zum altchristlichen und gregorianischen Gesang, Frankfurt am Main 1923; P. Lehmann, Ein Cicerofragment(?) in Oslo, „Symbolae Osloenses”, 17, 1937, s. 57-66.

${ }^{8} \mathrm{Na}$ problem zwracali uwagę m.in. A. Birkenmajer, W sprawie rejestracji i katalogowania opraw zabytkowych, w: Studia nad książka poświęcone pamięci Kazimierza Piekarskiego, Wrocław 1951, s. 112; K. Häbler, Makulatur-Forschung, „Zentralblatt für Bibliothekswesen”, 1908, nr 25, s. 535-544.

9 Przykładowo zob. K.A. Barack, Die Handschriften Fürstlich; E. Grönblad, Tvenne Medeltidshandlingar, „Suomi, Tidskrift i fosterländska ämnen 1846”, 1847, s. 202-260; tenże, Notiser, „Litteraturblad för Allmän Medborgerlig Nildning”, 1851, nr 5, s. 247-253; P.A. Munch, Levninger af norsk Oldlitteratur, s. 25-52.
} 
informacje na temat zabytku, podstawowy opis fizyczny, tekst oraz próby identyfikacji ${ }^{10}$. Wraz z pojawianiem się nowych i specjalistycznych czasopism nastąpiła szersza i sprawniejsza wymiana informacji, a same badania stawały się coraz bardziej interdyscyplinarne. Jako pierwsi wartość badań makulaturowych dostrzegli filolodzy, którzy poszukiwali głównie najstarszych tekstów powstałych w językach rodzimych. Badania nad fragmentami skoncentrowane były wówczas zasadniczo na analizie tekstów, identyfikacji oraz ewentualnej rekonstrukcji tak części niezachowanych, jak i całych rękopisów ${ }^{11}$.

W XX w. powszechną praktyką stało się wyodrębnianie średniowiecznej makulatury rękopiśmiennej z kodeksów i jednostek archiwalnych oraz tworzenie osobnych kolekcji ${ }^{12}$. Wiele bibliotek ma odpowiednie katalogi oraz inwentarze, zarówno w formie drukowanej, jak i cyfrowej, a coraz częstszą praktyką jest tworzenie internetowych bazach danych, w których dostępne są wysokiej jakości kopie cyfrowe. $\mathrm{W}$ ostatnich kilku latach badania nad fragmentami zyskały na popularności. Powstało wiele inicjatyw i projektów badawczych, blogów, książek i konferencji poświęconych rękopiśmiennej makulaturze średniowiecznej oraz luźnym fragmentom. Istnieje kilka projektów wartych odnotowania ze względu na międzynarodowy zasięg oraz zaawansowanie prac i warto $\mathrm{w}$ tym miejscu wspomnieć kilka $\mathrm{z}$ nich.

Jednym z najpopularniejszych obecnie projektów jest międzynarodowa biblioteka cyfrowa Fragmentarium, umożliwiająca publikowanie skanów fragmentów średniowiecznych rękopisów, katalogowanie, opisywanie, transkrypcję, gromadzenie i ponowne wykorzystywanie znajdujących się tam zasobów ${ }^{13}$. Również badania prowadzone już od XIX w. w krajach nordyckich zaowocowały szeregiem analogicznych inicjatyw. W Finlandii w 2011 r. w bazie Fragmenta Membranea udostępniono ponad 9 tys. zeskanowanych fragmentów z ok. 1500 rękopisów z okresu od XI do połowy XVI w. ${ }^{14} \mathrm{~W}$ Szwecji od lat 20. do 60. XX w. rejestrowano karty pergaminowe wykorzystane w czasach nowożytnych do oprawiania jednostek archiwalnych. Efektem prac był katalog kartkowy Catalogus Codicum Mutilorum (CCM) obejmujący ok. 15 tys. jednostek ${ }^{15}$. Kontynuację tych działań stanowił projekt Medeltida PergamentOmslag (MPO) trwający w latach 1995-2004 ${ }^{16}$. Oba przedsięwzięcia połączono w jedną bazę danych, zawierającą ok. 23 tys. fragmentów, dostępną w Internecie od 2013 r. ${ }^{17}$ Katalogowanie oraz digitalizacja zostały zakończone, a fragmenty, które udało się już zidentyfikować jako pochodzące z tych

${ }^{10}$ Przykładowo zob. C.G. Anton, Beschreibung dreyer Fragmente einer alten Bibel-Übersetzung in deutschen Versen, „Magazin für die Deutsche Sprache”, 1782, s. 103-129; J. Kinderling, Beytrag zur Deutschen Sprachkunde, durch Fragmente aus alten Deutschen Handschriften und seltenen gedruckten Büchern, „Magazin für die Deutsche Sprache”, 1783, s. 32-99. H.G. von Bretschneider, Gedanken über ein altes Bauernlied, „Historisch-litterarisch-bibliographisches Magazin”, (Zürich) 1790, s. 81-90.

${ }^{11}$ Jedne z pierwszych katalogów fragmentów obejmujący rekonstrukcję rękopisów zob. T. Haapanen, Verzeichnis der mittelalterlichen Handschriftenfragmente in der Universitätsbibliothek zu Helsingfors. I. Missalia, Helsingin yliopiston kirjaston julkaisuja, t. 4, Helsingfors 1922; tenże, Verzeichnis der mittelalterlichen Handschriftenfragmente in der Universitätsbibliothek zu Helsingfors. II. Gradualia, lectionaria missae, Helsingin yliopiston kirjaston julkaisuja, t. 7, Helsingfors 1925; tenże, Verzeichnis der mittelalterlichen Handschriftenfragmente in der Universitätsbibliothek zu Helsingfors. III. Breviaria, Helsingfors Universitetsbiblioteks Skrifter, t. 16, Helsingfors 1932.

12 Przykładem mogą być chociażby kraje nordyckie, np. w Finlandii już w latach 40. i 50. XIX w. zaczęto systematycznie wyodrębniać makulaturę średniowieczną i tworzyć osobną kolekcję, a następnie rekonstruować kodeksy oraz publikować katalogi. W Szwecji i Norwegii nastąpiło to ok. lat 20. XX w., a w Danii w latach 40. XX w. Bayerische Staatsbibliothek w Monachium posiada obszerny zbiór średniowiecznych fragmentów rękopiśmiennych wyciągniętych z opraw książek w XIX w.

${ }^{13}$ Biblioteka cyfrowa współtworzona przez: Bibliothèque national de France, British Library, Schøyen Collection, Bayerische Staatsbibliothek, Harvard University Houghton Library, Yale University Library i Biblioteca Apostolica Vaticana. Główna siedziba znajduje się w Szwajcarii; Fragmentarium, <https://fragmentarium.ms/>.

${ }_{14}$ Fragmenta Membranea, <https://fragmenta.kansalliskirjasto.fi/> [dostęp: 12.12.2018].

15 Więcej zob. Latin Manuscripts of Medieval Norway. Studies in Memory of Lilli Gjerløw, red. E. Karlsen, Oslo 2013.

${ }^{16}$ Riksarkivet, Medeltida PergamentOmslag, <https://sok.riksarkivet.se/mpo> [dostęp: 12.12.2018].

${ }_{17}$ Obecnie baza obejmuje zbiory Archiwum Narodowego oraz archiwów krajowych w Göteborgu, Härnösand, Östersund, Uppsali i Vadstena, Bibliotekę Królewską, biblioteki Uniwersytetu w Uppsali i BN w Helsinkach oraz wielu mniejszych instytucji: Muzeum Dalarna, Biblioteki Uniwersyteckiej w Göteborgu, Muzeum Historycznego, Szkoły Średniej im. Per Brahe w Jönköping, Muzeum Småland, Archiwów Sztokholmskich, Archiwum Stora-Enso w Falun, Värmlandsarkiv, Archiwum Miejskiego w Västervik. 
samych rękopisów, zostały odpowiednio oznaczone. Jednakże systematyczna rekonstrukcja kodeksów nie została jeszcze podjęta.

W Norwegii pierwszą instytucją, która opublikowała swoją kolekcję fragmentów, był Uniwersytet w Bergen ${ }^{18}$. W latach 2012-2017 prowadzony był projekt From Manuscript Fragments to Book History. Norway and the European Manuscript Culture 1100-1300, którego celem było przebadanie początków historii książki oraz kultury piśmiennej w Norwegii. W trakcie jego trwania przebadano ok. 6500 fragmentów znajdujących się w zbiorach instytucjonalnych. Na stronie internetowej projektu zobaczyć można próby wirtualnego odtworzenia składek kodeksów z mniejszych fragmentów, wykorzystanych głównie jako wzmocnienia szycia ${ }^{19}$. W latach 70 . XX w. ukazał się inwentarz zawierający ponad 5 tys. fragmentów, czyli ok. 90\% zbiorów duńskiego Archiwum Narodowego ${ }^{20}$. Pozostałą część opracował i opublikował w formie bazy danych w latach 2000-2002 Knud Ottosen ${ }^{21}$, natomiast duńska Biblioteka Królewska zdigitalizowała część najstarszej kolekcji fragmentów pochodzących z lat ok. 600-1500 i udostępniła na stronie Fragmenta Latina Hauniensia ${ }^{22}$.

Na uwagę zasługuje z pewnością wiele czeskich katalogó $\mathrm{w}^{23}$ oraz projekt Manuscriptorium ${ }^{24}$, którego głównym celem jest gromadzenie oraz udostępnianie wersji cyfrowych m.in. rękopisów średniowiecznych, w tym także fragmentów. Warte odnotowania są także projekty i bazy austriackich oraz niemieckich bibliotek. Biblioteka Uniwersytetu w Salzburgu prowadzi internetowy katalog fragmentów rękopiśmiennych z okresu od VII do XVI w. ${ }^{25}$ Rekordy zawierają szczegółowy opis fizyczny oraz treść, a same fragmenty zostały zdigitalizowane. Katalog można indeksować na kilka różnych sposobów - według języka, autora lub tytułu fragmentu, inicjałów, proweniencji oraz sygnatury. Austriacka Biblioteka Narodowa w 2017 r. rozpoczęła projekt mający na celu skatalogowanie oraz digitalizację fragmentów średniowiecznych pochodzących z benedyktyńskiego opactwa Mondsee, obecnie 81 opracowanych i zdigitalizowanych fragmentów można przeglądać w bibliotece cyfrowej Fragmentarium. W sierpniu 2017 r. frankfurcka Biblioteka Uniwersytecka ukończyła digitalizację zbioru średniowiecznych fragmentów rękopiśmiennych, które zostały wcześniej ujęte w osobnym katalogu przez Gerhardta Powitza w 1994 r. ${ }^{26}$ W Państwowej i Uniwersyteckiej Bibliotece w Hamburgu w 2009 r. ukazał się katalog fragmentów autorstwa rosyjskiego muzykologa Viacheslava Kartsovnika ${ }^{27}$. Katalog zawiera opis 417 fragmentów w językach łacińskim i niemieckim, pochodzących z okresu od IX do XVI w. Część kolekcji została już zdigitalizowana.

Badania nad fragmentami nie ograniczają się do kręgu łacińskojęzycznego czy też do poszukiwań tekstów w językach rodzimych. Bardzo dużą popularnością cieszy się również eksploracja zabytków języka hebrajskiego. Projektem zyskującym coraz większą renomę jest Books within Books: Hebrew Fragments in European Libraries ${ }^{28}$. Jego realizację rozpoczęto w 2007 r. i był pomyślany jako platforma

18 Digital fragment collection. Medieval parchment fragments in Bergen University Library and The Regional State Archives in Bergen, <http://ub.uib.no/fragment/list/index.html> [dostęp: 24.03.2019].

${ }_{19}$ From Manuscript Fragments to Book History, <http://fragment.uib.no/?> [dostęp: 18.02.2019].

${ }^{20}$ Middelalderlige håndskriftfragmenter: aftagne fragmenter. Omslag om lensregnskaber, oprac. E. Albrechtsen, København 1976.

${ }_{21}$ Danish Liturgical Fragments from the Middle Ages, <http://www.liturgy.dk/> [dostęp: 12.12.2018].

${ }^{22}$ Fragmenta Latina Hauniensia, <http://www.kb.dk/en/nb/materialer/haandskrifter/HA/e-mss/flh.html> [dostęp: 18.02.2019].

${ }^{23}$ Rukopisné zlomky Knihovny Národního muzea. Sbírky Adolfa Patery a Čeňka Zíbrta, wyd. M. Dragoun, J. Marek, Scriptorium, Praha 2012; Rukopisné zlomky Knihovny Národního muzea - Signatura 1 A, wyd. M. Brčák i in., Scriptorium, Praha 2014; Rukopisné zlomky Knihovny Národního muzea - Signatura 1 B a 1 C, wyd. J. Beneš i in., Scriptorium, Praha 2015; Rukopisné zlomky Knihovny Národního muzea - Signatury 1 D, 1 E a 1 G, wyd. V. Brom, V. Čermák, M. Dragoun, Scriptorium, Praha 2016; Rukopisné zlomky Knihovny Národního muzea - Signatura 1 K (Dodatky ke sbirkám Adolfa Patery a Čeňka Zíbrta, wyd. M. Dragoun, Scriptorium, Praha 2017.

${ }^{24}$ Manuscriptorium. Digital Library of Written Culture Heritage, <http://www.manuscriptorium.com/> [dostęp: 22.03.2018].

${ }^{25}$ Verzeichnis der Handschriftenfragmente der Universitätsbibliothek Salzburg, <http://www.ubs.sbg.ac.at/sosa/fragmente/ handschriftenfragmente.htm> [dostęp: 24.03.2018].

${ }^{26}$ G. Powitz, Mittelalterliche Handschriftenfragmente der Stadt- und Universitätsbibliothek Frankfurt am Main, Frankfurt am Main 1994.

${ }^{27}$ V. Kartsovnik, Folia Latina Hamburgensia. Die Fragmente lateinischer Handschriften vom 9. bis 16. Jahrhundert der Staats- und Universitäts-Bibliothek Hamburg, Hamburg 2009.

${ }^{28}$ Books within Books. Hebrew Fragments in European Libraries, <http://hebrewmanuscript.com/> [dostęp: 24.03.2019]. 
do wymiany informacji między mniejszymi inicjatywami oraz gromadzenia i przekazywania danych o wszelkich zachowanych fragmentach w języku hebrajskim ${ }^{29}$.

Wspólną cechą wszystkich tych projektów jest jednolity charakter podstawowych informacji zawartych $\mathrm{w}$ formularzu badawczym. Zaliczyć do nich należy: tytuł, sygnaturę, materiał, miejsce i czas powstania oraz proweniencję. Opis fizyczny obejmuje przynajmniej wysokość i szerokość fragmentu, ale często zawiera także bardziej szczegółowe informacje dotyczące liczby oraz wysokości i szerokości kolumn, odstępu między nimi, liczby linii i ich szerokości oraz szerokości marginesów, a czasem także kształtu i wymiaru otworów po nakłuciach potrzebnych do wyrysowywania linii. Szczegółowo opisuje się także dekoracje oraz pismo. Odnotowuje się ilość rąk, wielkość liter i inicjałów, ich kolorystykę oraz kolor atramentu. Informacje na temat wykorzystanego materiału (papier i/lub pergamin) uzupełniane są o ocenę jego koloru, jakości i grubości materiału, a także stan zachowania (np. cała karta/ bifolium), widoczność pisma, jak też wzmianki o innych charakterystycznych elementach, powstałych w skutek celowego działania lub warunków naturalnych (np. robactwo, zalanie), które umożliwiają jednoznaczne zidentyfikowanie fragmentów jako pochodzących $\mathrm{z}$ tego samego rękopisu. W trakcie rekonstrukcji zwraca się uwagę także na otwory po szyciu (rozmiar, kształt, odległość między otworami), umiejscowienie pierwszej linii tekstu - nad pierwszą wyrysowaną linią czy pomiędzy pierwszą i drugą, wszelkie poprawki w tekście, glosy, foliację (czy nadana tą samą ręką). W przypadku rękopisów muzycznych warto odnotować wysokość i odstępy między pięcioliniami oraz samą ilość linii, a także wysokość i wielkość kluczy oraz nut. Formularze zawierają z reguły miejsce na odnotowanie uwag.

Badania makulatury introligatorskiej w Polsce sięgają XIX w. i podobnie jak w przypadku innych krajów opierały się na przypadkowych znaleziskach, a nie systematycznym przeszukiwaniu zbiorów. Już w 1820 r. Michał Hieronim Juszyński pisał o konieczności przeglądania każdej księgi z osobna w celu dokładanego przeanalizowania nie tylko treści kodeksu, ale także materiału użytego do tworzenia księgi, gdyż w ten sposób mogły zostać wykorzystane istotne polskie dzieła, niegdyś uznane za zaczytane, niepotrzebne bądź niemożliwe do odczytania ${ }^{30}$. Poszukiwania makulatury, głównie w starych drukach, dość intensywnie prowadzone były w XIX w. m.in. w Bibliotece Jagiellońskiej, gdzie Jerzy Samuel Bandtkie odnalazł dwa fragmenty korektowych arkuszy ksiąg liturgicznych Triodon Postnaja i Czasosłowca (Ink. 1376), wydrukowanych w Krakowie w 1491 r. Nieco później Józef Muczkowski badając makulaturę również głównie w starych drukach, m.in. w oprawie nieznanego kodeksu trafił na próbne druki Jana Gutenberga (pośród nich znajdował się drukowana w Moguncji karta z Kalendarza na r. 1448). Dzięki działaniom Karola Estreichera Biblioteka Jagiellońska zyskała zaś pokaźną liczbę staropolskich kalendarzy oraz modlitewników wydobytych z opraw m.in. Raju dusznego w thumaczeniu Biernata z Lublina ${ }^{31}$.

W XIX w. odnaleziono kilka cennych zabytków języka polskiego, lecz przełomowym odkryciem w kategorii fragmentów było z pewnością odnalezienie przez Aleksandra Brücknera Kazań świętokrzyskich (ob. BN, sygn. 8001), które przetrwały jako wzmocnienie nici szycia składek w XV-wiecznym rękopisie łacińskim ${ }^{32}$. Odkrycie to spowodowało, że nie tylko zaczęto zwracać uwagę na makulaturę w kodeksach, ale i także zaczęto ją wyodrębniać z rękopisów. W latach 30. XX w. Kazimierz Piekarski wraz z Bonawenturą Lenartem podjęli się zadania rozklejenia opraw makulaturowych ze zbiorów Archiwum Głównego Akt Dawnych, gdzie udało się odnaleźć 35 fragmentów rękopiśmiennych i 67 drukowanych ${ }^{33}$. Konstanty Michalski w 1923 r. odkrył Pasje połockq - datowane na przełom

${ }^{29} \mathrm{~W}$ bazie znajdują się także fragmenty z polskich zbiorów - z Krakowa (131), Tarnowa (3) i Wrocławia (16).

${ }^{30}$ M.H. Juszyński, Dykcjonarz poetów polskich, t. 1, Kraków 1820, s. 15.

${ }^{31}$ A. Lewicka-Kamińska, Narastanie zasobu starych druków Biblioteki Jagiellońskiej, „Przegląd Biblioteczny”, 32, 1964, nr 4, s. 216.

32 W XIX w. odnaleziono m.in. Kartę medycka, Fragment Łopacińskiego, Kartę Glogera, Kartę Malinowskiego.

${ }^{33}$ K. Piekarski, Fragmenty czterech nieznanych wydań „,Marchołta”, „Pamiętnik Literacki”, 1935, s. 484. Warto odnotować, że efektem zabiegów konserwatorskich Bonawentury Lenarta jest m.in. karta z rękopisu datowanego na przełom VIII i IX w., zawierająca tekst Regulae pastoralis Grzegorza Wielkiego, zapisanego półuncjałą iryjską - ob. BN akc. 9396; zob. Inwentarz rękopisów do połowy XVI wieku w zbiorach Biblioteki Narodowej, oprac. J. Kaliszuk, S. Szyller, Inwentarze Rękopisów Biblioteki Narodowej, t. 3, Warszawa 2012, s. 212. 
XIV i XV w. polskie tłumaczenie Złotej legendy Jakuba de Voragine. Tekst ten zapisany był na dwóch pergaminowych kartach formatu folio, wykorzystanych wtórnie jako oprawy rękopisów ${ }^{34}$. W latach 50. XX w. uwagę na przydatność analizy makulatury w badaniach opraw książkowych zwrócił Aleksander Birkenmajer, który pisał, że w przypadku braku możliwości jednoznacznego rozstrzygnięcia proweniencji oprawy warto sięgnąć do materiału wykorzystanego przez introligatora $\mathrm{w}$ procesie oprawiania kodeksu ${ }^{35}$. Jednym z najnowszych odkryć jest z pewnością odnalezienie ponad 60 fragmentów w oprawie księgi metrykalnej z Mszany ${ }^{36}$, kart rękopiśmiennych z kodeksu pochodzącego z klasztoru cystersów w Łeknie-Wągrowcu ${ }^{37}$ oraz XV-wiecznej karty zawierającej nieznane kazanie w języku polskim ${ }^{38}$.

W polskich katalogach rękopisów makulatura, jeśli jest integralną częścią kodeksu, także bywa odnotowywana, a niekiedy i identyfikowana. Obecnie w Polsce nie ma jednak osobnego katalogu czy nawet inwentarza fragmentów rękopiśmiennych. Jedynym, z którym się spotkałam, jest rękopiśmienny inwentarz Archiwum Archidiecezjalnego w Gnieźnie, gdzie odnotowanych zostało 314 fragmentów ${ }^{39}$. Takich „roboczych” inwentarzy czy kartotek, sporządzanych na potrzeby danej instytucji, może być więcej, niestety zwykle nie mamy świadomości ich istnienia, gdyż dostępne są jedynie na miejscu. W konsekwencji skazani jesteśmy na badania o charakterze wybiórczym, ograniczone do jednej instytucji.

W 2018 r. przeprowadzono taką kwerendę w Archiwum Państwowym w Szczecinie. W efekcie żmudnego przeszukania kilku zespołów archiwalnych odnaleziono 709 fragmentów wykorzystanych jako oprawy oraz elementy przybyszowe nowożytnych jednostek archiwalnych. Znakomitą większość tej makulatury stanowią karty pergaminowe, liczbę fragmentów papierowych szacuję na zaledwie kilka sztuk, które zostały zresztą wykorzystane wyłącznie jako elementy przybyszowe, gdyż nie stanowiły równie przydatnego i solidnego materiału jak pergamin. Oprawy najczęściej wykonywane były z całego bifolium lub karty formatu dużego folio - $\mathrm{z}$ podwinięciami $\mathrm{w}$ celu dostosowania do mniejszego formatu akt lub rzadziej z odpowiednio przyciętych kart. Fragmenty te obejmują przednią i tylną okładkę oraz grzbiet akt, rzadziej stanowią dwa osobne fragmenty wykorzystane jako przednia i tylna oprawa, założone falcem za pierwszą lub ostatnią składkę. Zdarzają się także - choć zdecydowanie rzadziej oprawy wykonane z pozszywanych kilku fragmentów oraz kart pergaminowych oklejonych dodatkowo papierem, gdzie możliwe jest jedynie ogólne stwierdzenie, że jest to makulatura pochodząca z średniowiecznego kodeksu. W wypadku elementów przybyszowych są to najczęściej wzmocnienia szycia, które wykonywane były z poskładanych kart lub ich fragmentów. Niekiedy bez odłączenia fragmentu od poszytu ciężko określić, czy wzmocnienie zostało wykonane z więcej niż jednego fragmentu.

Efektem kolejnych kwerend było odnalezienie następnych fragmentów przechowywanych obecnie w Bibliotece Narodowej oraz Archiwum PAN w Warszawie, a pochodzących z AP w Szczecinie. W BN znajduje się 7 jednostek akcesyjnych zawierających 367 fragmentów papierowych oraz pergaminowych, w Archiwum PAN zaś przechowywane są 2 fragmenty (bifolia) ${ }^{40}$.

Znaczna część fragmentów ze wspomnianych jednostek akcesyjnych BN bez wątpienia pochodzi ze szczecińskiego AP. Noszą one charakterystyczne dla tamtejszych akt noty archiwalne, sygnatury oraz ślady złożenia i wykorzystania jako oprawy. Problematyczne są dwie jednostki: akc. 16483 zawierająca 5 kart pergaminowych z Officium parvum Beatae Mariae Virginis oraz akc. 16486 obejmująca 40 kart z rękopisów liturgicznych. Niestety żadna z zachowanych kart nie nosi śladów wykorzystania jako oprawy jednostki archiwalnej, brak też charakterystycznych sygnatur szczecińskich. Być może dalsze

\footnotetext{
${ }^{34}$ Zob. Chrestomatia staropolska. Teksty do roku 1543, oprac. W. Wydra, W.R. Rzepka, wyd. 3, Wrocław 2004, s. 115 n.

35 A. Birkenmajer, $W$ sprawie rejestracji, s. 112.

36 Tajemnice kompaturek. Księga metrykalna z Mszany (1638-1775), red. H. Dudała, Katowice 2016.

37 J. Łukaszewski, Odnalezione fragmenty najstarszego kodeksu rękopiśmiennego z klasztoru cystersów w Leknie-Wągrowcu, „Biblioteka”, 19, 2015, s. 31-45.

38 J. Łukaszewski, W. Wydra, Nieznane kazanie(?) polskie z około połowy XV wieku ze zbiorów gnieźnieńskich, „Biuletyn Biblioteki Jagiellońskiej”, 66, 2016, s. 5-14.

39 Inwentarz fragmentów rękopiśmiennych MsFragm A: nr 1 - Pergaminy. Rozpoczęto 30 maja 1969 r., rkps, Gniezno 1969.

${ }^{40}$ BN: akc. 6322,1-6; akc. 16483; akc. 16486; akc. 16487; akc. 16488; akc. 16489; akc. 16490; Archiwum PAN w Warszawie, sygn. 171.
} 
badania umożliwią bezsporne określenie ich proweniencji. Obecnie jedynym argumentem na rzecz ich „szczecińskiego" pochodzenia może być czas pozyskania do BN oraz informacje zawarte w księdze akcesyjnej. W Inwentarzu rękopisów do połowy XVI wieku w zbiorach Biblioteki Narodowej przy proweniencji tych jednostek zawarto następujące informacje: „Szczecin, Archiwum Państwowe?, Ludwik Kolankowski?” oraz „Naczelna Dyrekcja Archiwów Państwowych” z adnotacją: „makulatura wyjęta z opraw" "11. W księdze akcesyjnej BN widnieje zaś informacja o przekazaniu tychże fragmentów w darze w 1952 r. przez Ludwika Kolankowskiego. Nie wiadomo, w jaki sposób badacz ten wszedł w ich posiadanie oraz kto i w jakich okolicznościach odłączył je od archiwaliów szczecińskich. W 1933 r., w związku z nowym rozmieszczeniem zespołów w magazynach archiwalnych, jednostki z zespołu Archiwum Książąt Szczecińskich zostały oznaczone sygnaturą: Repozytura 4 (Rep. 4 Herzoglich Stettiner Archiv), natomiast jednostki z zespołu Archiwum Książąt Wołogoskich sygnaturą Repozytura 5 (Rep. 5 Herzoglich Wolgaster Archiv). Fragmenty w BN oznaczeń tych nie mają, można więc przyjąć, że zostały wyodrębnione z akt wcześniej i w 1933 r. nie stanowiły już integralnych części jednostek archiwalnych. Przypuszczenie to potwierdza artykuł Hansa Frederichsa z 1931 r. pt. Missa sancti Ottonis, w którym autor wspomina o zbiorze luźnych fragmentów znajdujących się w AP w Szczecinie ${ }^{42}$.

Szczecińskie jednostki archiwalne zawierające oprawy pergaminowe znajdują się w kilku zespołach, niektóre zostały utworzone we wczesnym okresie nowożytnym. Zespoły te nie zachowały się w stanie nienaruszonym. Część akt uległa zniszczeniu lub rozproszeniu i znalazła się w zbiorach niemieckich. Największy zbiór opraw pergaminowych z rękopisów znajduje się obecnie w zespole Archiwum Książąt Szczecińskich - ok. 469 fragmentów pochodzących z 424 jednostek archiwalnych oraz w Archiwum Książąt Wołogoskich - ok. 205 fragmentów ze 173 jednostek archiwalnych. Powstanie tych dwóch archiwów książęcych wiąże się ściśle z rokiem 1532, kiedy to Filip I i Barnim XI zawarli układ, na mocy którego podzielono księstwo pomorskie na część szczecińską i wołogoską. Umowa ta powodowała podział nie tylko państwa na dwa księstwa, ale także archiwaliów. Akta odnoszące się do zarządu gospodarczego zostały wówczas podzielone według zasady przynależności terytorialnej. Kwestią znacznie trudniejszą do rozwiązania były archiwalia dotyczące zwierzchności państwowej. W myśl zawartego układu oba księstwa zobowiązały się do prowadzenia wspólnej polityki zagranicznej i ogólnopaństwowej. Aby sprostać wymaganiom, obie kancelarie musiały zatem posiadać komplet dokumentów ${ }^{43}$. Zadecydowano, że dokumenty pozostaną w Wołogoszczy, gdzie powstanie archiwum centralne, a książęta szczecińscy otrzymają wykaz oraz odpisy ważniejszych dokumentów ogólnokrajowych, korespondencji i innej niezbędnej dokumentacji ${ }^{44}$. Po śmierci Filipa Juliusza, ostatniego księcia z wołogoskiej linii Gryfitów, w latach 1628-1642 archiwum wołogoskie zostało przeniesione do Szczecina ${ }^{45}$. W $1642 \mathrm{r}$. akta złożono na zamku szczecińskim, gdzie scalono wszystkie części zespołu i uporządkowano według Archiwum Książąt Szczecińskich ${ }^{46}$. Zespół ten od początku istnienia przechowywany był na zamku w Szczecinie. Historyczne archiwum istniało także na Pomorzu w okresie panowania szwedzkiego i brandenburskiego. W 1648 r. Szczecin wraz z archiwaliami przypadł Szwecji. Szwedzi stworzyli własną kancelarię, a z archiwum wyłączono niektóre akta niezbędne w bieżącej pracy registratury. Znalazły się one w kancelarii szwedzkiej i zostały wywiezione do Sztokholmu. Kolejne uszczuplenia zasobu nastąpiły po 1677 r., gdy Szczecin został zdobyty przez wojska Fryderyka Wilhelma, a część akt wywieziona do Berlina oraz prawdopodobnie w 1713 r., gdy wojska rosyjskie splądrowały zamek szczeciński ${ }^{47}$.

${ }^{41}$ Zob. Inwentarz rękopisów do połowy XVI wieku w zbiorach Biblioteki Narodowej, s. $231 \mathrm{n}$.

${ }^{42}$ H. Frederichs, Missa sancti Ottonis, „Baltische Studien”, Neue Folge, 33, 1930, nr 1-2, s. 49-63.

${ }^{43}$ L. Turek-Kwiatkowska, Z dziejów stużby archiwalnej. Archiwa na Pomorzu Zachodnim w latach 1808-1914, Warszawa 1968, s. 17 n.

${ }_{44}$ F. Barthold, Geschichte von Rügen und Pommern, t. 4, cz. 2, Hamburg 1845, s. 241.

${ }^{45}$ F.L. von Medem, Das Königliche Provinzial-Archiv zu Stettin, „Zeitschrift für Archivkunde, Diplomatik und Geschichte”, 2, 1835, s. 30 n.

46 Archiwum Książąt Wołogoskich w zasobach Archiwum Państwowego w Szczecinie i Landesarchiv Greifswald, oprac. A. Łazarek, U. Rodig, Warszawa-Greifswald-Szczecin 2005, s. 13.

${ }^{47}$ A. Wielopolski, Archiwum Książąt Szczecińskich, „Archeion”, 38, 1962, s. 32. 
W okresie pruskim (od początku XVIII w. do 1945 r.) szczecińskie archiwum stało się profesjonalną placówką. Przejęło wówczas wytworzone wcześniej zbiory. Archiwum w Szczecinie formalnie utworzono w 1831 r., a jego siedzibą został Zamek Książąt Pomorskich. Do zasobu przejęto akta rejencji, sądów, różnych fundacji i archiwalia kościelne. W 1900 r. archiwum przeniesiono do nowego gmachu, przy dzisiejszej ul. św. Wojciecha $13^{48} .1$ sierpnia 1945 r. zostało przejęte przez polskich archiwistów.

W czasie II wojny światowej zespoły Archiwum Książąt Wołogoskich i Archiwum Książąt Szczecińskich podzielono na dwie, nierówne pod względem wielkości, części. Większa część tych akt trafiła do położonego na wschód od Stargardu zamku w Pęzinie (Pansin), skąd po zakończeniu wojny powróciły do Szczecina. Zgodnie z zasadą proweniencji i pertynencji terytorialnej miały zostać przekazane stronie niemieckiej ${ }^{49}$. Nie doszło jednak do tego i archiwalia pozostały w utworzonym 1 sierpnia $1945 \mathrm{r}$. Archiwum Państwowym w Szczecinie. W 2002 r. ostatecznie opracowano tenże zespół i sporządzono nowy inwentarz. Obecnie Archiwum Książąt Wołogoskich liczy 1934 j.a., a Archiwum Książąt Szczecińskich - 9142 j.a. Pozostałe akta zespołu Archiwum Książąt Wołogoskich trafiły do Schwerinsburga, a akta zespołu Archiwum Książąt Szczecińskich znalazły się w Spantekow na Rugii. Zostały zabezpieczone przez niemieckich archiwistów pod koniec lat 50. XX w. i przewiezione do Archiwum Państwowego w Greifswaldzie, gdzie obecnie znajduje się 636 j.a. z Archiwum Książąt Wołogoskich oraz 2600 j.a. z Archiwum Książąt Szczecińskich ${ }^{50}$.

Pozostała część makulatury - 35 fragmentów - zachowała się w siedmiu kolejnych zespołach archiwum szczecińskiego: Kościół św. Jakuba w Szczecinie (Jacobikirche in Stettin), Kapituła Katedralna w Kamieniu Pomorskim (Domkapitel Cammin), Fundacja Najświętszej Marii Panny w Szczecinie (Marienstift in Stettin), Kościół Najświętszej Marii Panny w Gryficach (Marienkirche in Greifenberg), Aktach miasta Chociwla (Magistrat Freinwalde), Kamera Wojenno-Skarbowa w Szczecinie (Krieges und Domänenkammer zu Stettin), Rękopisy i Spuścizny (Manuskripte und Nachlässe) ${ }^{51}$.

Jednym z najważniejszych pytań, które pojawiają się w przypadku opraw z rękopisów średniowiecznych, jest kwestia, kiedy i gdzie zostały one wykonane oraz czy jest możliwe, że akta zostały oprawione w tym samym miejscu i czasie, co oznaczałoby jednorazowe wykorzystanie kart z kodeksów. Anna Łazarek w publikacji poświęconej Archiwum Książąt Wołogoskich, wydanej wraz z Uwe Rodigiem, pisała, że „na początku lat 70. XIX w. zaczęto łączyć małe jednostki, a nowo powstałe grube poszyty oprawiano w stare pergaminy z kodeksów" ${ }^{52}$. Teza ta wydaje się mało prawdopodobna - w owym czasie doceniano już znaczenie makulatury z rękopisów średniowiecznych jako nośników rzadkich tekstów; co więcej, trudno sobie wyobrazić, by w archiwum w tym okresie (pół wieku po rozpoczęciu wydawania serii MGH) rozdzierano średniowieczne rękopisy pergaminowe, uznając je za zbędne.

Wykonanie opraw makulaturowych w obu zespołach (Archiwum Książąt Wołogoskich i Archiwum Książąt Szczecińskich) mogło zatem nastąpić stosunkowo wcześnie i niezależnie od siebie, zanim zbiory zostały połączone w Szczecinie. Możliwe, że proces ten trwał kilkadziesiąt lat i nie był efektem jednorazowej akcji, lecz fragmenty były wykorzystywane sukcesywnie w miarę tworzenia jednostki archiwalnej. Jeśli jednak oprawienie w makulaturę rękopiśmienną nastąpiło w tym samym momencie, to można przypuszczać, że stało się to podczas porządkowania akt, czyli w 1642 r., kiedy przeniesiono do Szczecina ostatnie jednostki z Archiwum Książąt Wołogoskich. Wówczas uporządkowano je na wzór Archiwum Książąt Szczecińskich. Inną cezurę chronologiczną może stanowić okres szwedzkiego panowania (formalnie 1648-1721), kiedy także przeprowadzono akcję porządkowania akt. Istnieje także prawdopodobieństwo, że akta w Archiwum Książąt Szczecińskich zostały oprawione wcześniej, a w Archiwum Książąt Wołogoskich w chwili jego przeniesienia do Szczecina. Wszystkie tezy dotyczące

\footnotetext{
48 J. Grzelak, Budynki Archiwum Państwowego w Szczecinie 1900-2000, „Szczeciński Informator Archiwalny”, 14-15, 2002, s. $14-17$.

49 J. Podralski, Zasada pertynencji terytorialnej w świetle materiałów Archiwum w Szczecinie, „Archeion”, 71, 1981, s. 29-31.

50 Archiwum Państwowe w Szczecinie. Przewodnik po zasobie archiwalnym. Akta do 1945 roku, oprac. R. Gaziński, P. Gut, M. Szukała, Warszawa-Szczecin 2002, s. 21-33.

${ }^{51}$ Akta wymienionych zespołów zostały przekazane do archiwum w XIX i XX w.; więcej na ten temat zob. tamże.

${ }^{52}$ Archiwum Książąt Wotogoskich, s. 17.
} 
czasu i miejsca oprawienia archiwaliów w okładki z rękopisów średniowiecznych mogą zostać zweryfikowane lub sfalsyfikowane wyłącznie po szczegółowej analizie wszystkich fragmentów. Wówczas możliwe będzie określenie, czy karty pochodzące $\mathrm{z}$ tego samego rękopisu średniowiecznego zostały wykorzystane na oprawy w obu zespołach. Jednak już obecnie można z dużym prawdopodobieństwem założyć, że samo oprawienie (niezależnie od powyższych wątpliwości) w obu zespołach - Archiwum Książąt Szczecińskich i Archiwum Książąt Wołogoskich - nastąpiło najpóźniej w XVII w. Jeśli zaś chodzi o pozostałe zespoły, z których większość akt trafiła do archiwum szczecińskiego dopiero w XIX i XX w., ich oprawienie nastąpić mogło w XVI-XVII w., lecz z pewnością nie w tym samym miejscu.

Analiza kodykologiczna i treściowa fragmentów szczecińskich stanowiących oprawy jednostek archiwalnych nie jest łatwa. Wiele kart poprzycinano, przez co utracono spore fragmenty tekstów. Część z nich oklejona została kartami papierowymi, na niektóre poprzyklejano kawałki papieru z nazwą zespołu oraz sygnaturą, a miejscami są bardzo zabrudzone i uszkodzone, co uniemożliwia identyfikację tekstu. Luźne fragmenty przechowywane w BN i Archiwum PAN w Warszawie są zaś poprzycinane, zdefektowane, a na skutek konserwacji często nie widać na nich not archiwalnych, co utrudnia zidentyfikowanie jednostek archiwalnych, z których mogą pochodzić.

Na podstawie wstępnych ustaleń można stwierdzić, że makulatura wykorzystana jako oprawy jednostek archiwalnych w zbiorach szczecińskich pochodzi z okresu od XII do XV w. W przeważającej większości są to rękopisy liturgiczne, teologiczne (komentarze do Pisma Świętego) oraz rękopisy prawnicze. Dobór treściowy wynikał oczywiście z użytego materiału pisarskiego (pergamin). Niewątpliwie fragmenty te pochodzą z kręgu kościelnego, zapewne bliżej niezidentyfikowanego lokalnego księgozbioru, być może z jednego ze zlikwidowanych w okresie reformacji klasztorów. Już na obecnym etapie badań można stwierdzić, że znaczna część fragmentów pochodzi z tych samych rękopisów wykorzystane karty i bifolia można ułożyć w przynajmniej częściowo zachowane składki. Przykładem jest chociażby XIV-wieczny rękopis zawierający Pismo Święte, którego fragmenty zachowały się jako oprawy 18 jednostek archiwalnych w zespole Archiwum Książąt Wołogoskich. Fragmenty te to bifolia oraz pojedyncze karty, zawierające w treści części kilku ksiąg biblijnych: Rodzaju, Kapłańską, Liczb, Rut, Jozuego, Mądrości oraz Pieśni nad pieśniami. Samych fragmentów obejmujących Księgę Rodzaju jest aż siedem, tzn. pięć pojedynczych kart i dwa bifolia, które pierwotnie znajdowały się w trzech sąsiadujących z sobą składkach. Rekonstrukcja przedstawia się następująco ${ }^{53}$ :

AKW 366:

Rdz. $18,12-19,15$

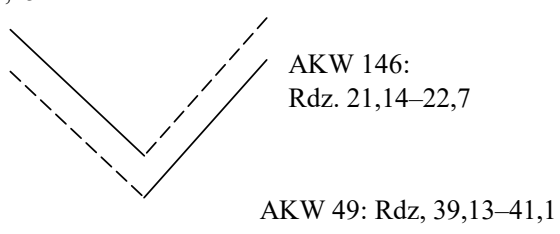

AKW 49: Rdz, 39,13-41,1

AKW 1702: Rdz, 37,13-38,1
AKW 48: Rdz. 26,24-28,18

AKW 810: Rdz. 30,7-37 AKW 1913: Rdz. 31,44-32,28

Legenda: AKW - Archiwum Państwowe w Szczecinie, Archiwum Książąt Wołogoskich

Obecnie zbiór „szczecińsko-warszawskiej” średniowiecznej makulatury rękopiśmiennej liczy ok. 1077 fragmentów. Ich szczegółowe opracowanie z pewnością przyniesie rekonstrukcję przynajmniej poszczególnych składek rękopisów. Badanie makulatury wykorzystanej na oprawy akt jest niezwykle istotne, gdyż daje możliwość przynajmniej częściowego zrekonstruowania niemal całkowicie nieznanych

${ }^{53} \mathrm{Na}$ rysunku podano sygnaturę jednostki archiwalnej oraz zakres treści zawarty we fragmencie. 
księgozbiorów średniowiecznych na Pomorzu Zachodnim, rozproszonych i zniszczonych już w czasach reformacji. Jeżeli nawet nie uda się przypisać zrekonstruowanych częściowo rękopisów jako należących do konkretnej instytucji kościelnej, to istotne jest stwierdzenie samego faktu funkcjonowania tych rękopisów, ale też określonych treści zawartych w tych kodeksach na Pomorzu Zachodnim w okresie średniowiecza, począwszy od XII w.

Innym problemem badawczym pozostaje uchwycenie i analiza jednostek archiwalnych zespołów, w których odnaleziono makulaturę, obecnie przechowywanych w archiwach niemieckich: Landesarchiv w Greifswaldzie (7165 j.a.) i Geheimes Staatsarchiv w Berlinie (2 j.a.). Wiadomo, że one również posiadają oprawy makulaturowe, nie wiadomo jednak, jak wiele jest takich fragmentów. Badanie fragmentów znajdujących się w AP w Szczecinie oraz pochodzących ze Szczecina i przechowywanych w BN jest więc pierwszym - najważniejszym - etapem badań fragmentologicznych tego cennego zachodniopomorskiego zbioru rękopiśmiennego. Badanie tych fragmentów może też rzucić nowe światło na dzieje kultury na obszarze państwa Gryfitów w okresie średniowiecza.

\section{Fragments of medieval manuscripts - the current research state and new prospects. The medieval fragments from the State Archives in Szczecin}

Summary: The article is an introduction to the current state of research on medieval manuscript fragments and presents preliminary conclusions from queries carried out in the State Archives in Szczecin, the National Library and the Archives of the Polish Academy of Sciences in Warsaw, during which over 1070 manuscript fragments used as bindings of archival units in the Szczecin Archives were discovered. The number and size of the preserved fragments make it possible to partially reconstruct entire codices and shed new light on the almost completely unknown medieval official book collections in Western Pomerania.

Nota o autorze: Karolina Kinga Figaszewska, mgr, doktorantka w Instytucie Historii Nauki im. Ludwika i Aleksandra Birkenmajerów Polskiej Akademii Nauk w Warszawie, pracownik projektu Manuscripta.pl.

Author: Karolina Figaszewska, PhD student at the at Ludwik and Aleksander Birkenmajer Institute for the History of Science, Polish Academy of Sciences, member of the Manuscripta.pl project.

Instytut Historii Nauki im. Ludwika i Aleksandra Birkenmajerów Polskiej Akademii Nauk

ul. Nowy Świat 72, pok. A09

00-330 Warszawa

e-mail: karolina.figaszewska@gmail.com

\section{Bibliografia}

\section{Źrodła}

Middelalderlige håndskriftfragmenter: aftagne fragmenter. Omslag om lensregnskaber, oprac. E. Albrechtsen, København 1976

Rukopisné zlomky Knihovny Národního muzea. Sbirky Adolfa Patery a Čeňka Zíbrta, wyd. M. Dragoun, J. Marek, Scriptorium, Praha 2012

Rukopisné zlomky Knihovny Národního muzea - Signatura 1 A, wyd. M. Brčák i in., Scriptorium, Praha 2014

Rukopisné zlomky Knihovny Národního muzea - Signatura 1 B a 1 C, wyd. J. Beneš i in., Scriptorium, Praha 2015

Rukopisné zlomky Knihovny Národního muzea - Signatury 1 D, 1 E a 1 G, wyd. V. Brom, V. Čermák, M. Dragoun, Scriptorium, Praha 2016

\section{Opracowania}

Archiwum Ksiażąt Wołogoskich w zasobach Archiwum Państwowego w Szczecinie i Landesarchiv Greifswald, oprac. A. Łazarek, U. Rodig, Warszawa-Greifswald-Szczecin 2005

Archiwum Państwowe w Szczecinie. Przewodnik po zasobie archiwalnym. Akta do 1945 roku, oprac. R. Gaziński,

P. Gut, M. Szukała, Warszawa-Szczecin 2002 
Barthold F., Geschichte von Rügen und Pommern, t. 4, cz. 2, Hamburg 1845

Birkenmajer A., W sprawie rejestracji i katalogowania opraw zabytkowych, w: Studia nad książka poświęcone pamięci Kazimierza Piekarskiego, Wrocław 1951, s. 105-121

Chlebus E., Elementy przybyszowe w oprawach późnogotyckich - formy, funkcje, terminologia, „Roczniki Biblioteczne", 61, 2017, s. 67-84

Chrestomatia staropolska. Teksty do roku 1543, oprac. W. Wydra, W.R. Rzepka, wyd. 3, Wrocław 2004

Encyklopedia wiedzy o ksiażce, red. A. Birkenmajer, Wrocław 1971

Frederichs H., Missa sancti Ottonis, „Baltische Studien”, Neue Folge, 33, 1930, nr 1-2, s. 49-63

Haapanen T., Verzeichnis der mittelalterlichen Handschriftenfragmente in der Universitätsbibliothek zu Helsingfors. I. Missalia, Helsingin yliopiston kirjaston julkaisuja, t. 4, Helsingfors 1922

Haapanen T., Verzeichnis der mittelalterlichen Handschriftenfragmente in der Universitätsbibliothek zu Helsingfors. II. Gradualia, lectionaria missae, Helsingin yliopiston kirjaston julkaisuja, t. 7, Helsingfors 1925

Haapanen T., Verzeichnis der mittelalterlichen Handschriftenfragmente in der Universitätsbibliothek zu Helsingfors. III. Breviaria, Helsingfors Universitetsbiblioteks Skrifter, t. 16, Helsingfors 1932

Häbler K., Makulatur-Forschung, „Zentralblatt für Bibliothekswesen”, 1908, nr 25, s. 535-544

Inwentarz fragmentów rękopiśmiennych MsFragm A: nr 1 - Pergaminy. Rozpoczęto 30 maja 1969 r., rkps, Gniezno 1969

Inwentarz rękopisów do połowy XVI wieku w zbiorach Biblioteki Narodowej, oprac. J. Kaliszuk, S. Szyller, Inwentarze Rękopisów Biblioteki Narodowej, t. 3, Warszawa 2012

Latin Manuscripts of Medieval Norway. Studies in Memory of Lilli Gjerløw, red. E. Karlsen, Oslo 2013

Kartsovnik V., Folia Latina Hamburgensia. Die Fragmente lateinischer Handschriften vom 9. bis 16. Jahrhundert der Staats- und Universitäts-Bibliothek Hamburg, Hamburg 2009

Lewicka-Kamińska A., Narastanie zasobu starych druków Biblioteki Jagiellońskiej, „Przegląd Biblioteczny”, 32, 1964, nr 4, s. 209-221

Medem F.L. von, Das Königliche Provinzial-Archiv zu Stettin, „Zeitschrift für Archivkunde, Diplomatik und Geschichte", 2, 1835, s. 29-199

Podralski J., Zasada pertynencji terytorialnej w świetle materiałów Archiwum w Szczecinie, „Archeion”, 71, 1981, s. 29-48

Powitz G., Mittelalterliche Handschriftenfragmente der Stadt- und Universitätsbibliothek Frankfurt am Main, Frankfurt am Main 1994

Turek-Kwiatkowska L., Z dziejów służby archiwalnej. Archiwa na Pomorzu Zachodnim w latach 1808-1914, Warszawa 1968

Wielopolski A., Archiwum Książąt Szczecińskich, „Archeion”, 38, 1962, s. 29-67

Wstęp do inwentarza zbioru akt Rękopisy i Spuścizny [Manuskripte und Nachlässe] z lat 1321-1946, oprac. J. Podralski, Szczecin 1994, mszp w zbiorach Archiwum Państwowego w Szczecinie

Wstęp do inwentarza zespolu Archiwum Książą Wołogoskich [Herzoglich Wolgaster Archiv] [1401] 1532-1638 [1732], oprac. A. Łazarek, Szczecin 2002-2003, mszp w zbiorach Archiwum Państwowego w Szczecinie

Wstęp do inwentarza zespolu Kościoła NMP w Gryficach, oprac. J. Podralski, Szczecin b.d.w., mszp w zbiorach Archiwum Państwowego w Szczecinie

Wstęp do inwentarza zespołu Kościoła św. Jakuba w Szczecinie, oprac. J. Podralski, Szczecin b.d.w., mszp w zbiorach Archiwum Państwowego w Szczecinie

Wstęp do inwentarza zespołu 65/37 Fundacja Najświętszej Marii Panny w Szczecinie, oprac. B. Frankiewicz, Szczecin 1985, mszp w zbiorach Archiwum Państwowego w Szczecinie

Wstęp do inwentarza zespolu nr 65/9 Kapituła Katedralna w Kamieniu Pomorskim (Domkapitel Kammin), oprac. H. Lesiński, Szczecin 1968, mszp w zbiorach Archiwum Państwowego w Szczecinie

Zawisza A., Kompaturki - nowe podejście do problemu, „Notes Konserwatorski”, 15, 2012, s. 149-155

\section{Bazy internetowe}

Books within Books. Hebrew Fragments in European Libraries, <http://hebrewmanuscript.com/> [dostęp: 24.03.2019] Danish Liturgical Fragments from the Middle Ages, <http://www.liturgy.dk/> [dostęp: 12.12.2018]

Digital fragment collection. Medieval parchment fragments in Bergen University Library and The Regional State Archives in Bergen, <http://ub.uib.no/fragment/list/index.html> [dostęp: 24.03.2019]

Fragmentarium, <https://fragmentarium.ms/>

Fragmenta Latina Hauniensia, <http://www.kb.dk/en/nb/materialer/haandskrifter/HA/e-mss/flh.html> [dostęp: 18.02.2019] 
Fragmenta Membranea, <https://fragmenta.kansalliskirjasto.fi/> [dostęp: 12.12.2018]

From Manuscript Fragments to Book History, <http://fragment.uib.no/?> [dostęp: 18.02.2019]

Handrit.is, Fragment AM 666 b 4to, <https://handrit.is/en/manuscript/view/en/AM04-0666-b> [dostęp: 11.02.2018] Manuscriptorium. Digital Library of Written Culture Heritage, <http://www.manuscriptorium.com/> [dostęp: 22.03.2018]

Riksarkivet, Medeltida PergamentOmslag, <https://sok.riksarkivet.se/mpo> [dostęp: 12.12.2018]

Verzeichnis der Handschriftenfragmente der Universitätsbibliothek Salzburg, <http://www.ubs.sbg.ac.at/sosa/fragmente/handschriftenfragmente.htm> [dostęp: 24.03.2018] 